\title{
Executorial Strength of Deed of Peace in Civil Dispute Resolution in Indonesia
}

\section{Endang Hadrian}

Faculty of Law, University of Bhayangkara, Jakarta Indonesia

endanghadrian@yahoo.co.id

\section{ABSTRACT}

Civil dispute resolution can be settled through peace institutions with the legal product in form of a deed of peace. However, this institution has not been used by many people even though it provides the civil dispute settlement the executorial strength faster. Thus, it offers no further legal remedies be it in the form of appeals and cassation. Practically, a deed of peace is known to have executorial strength. However, some parties pursue the legal effort despite the peace settlement in the form of the deed of peace. The optimization of the use of the peace institution with executorial strength is expected to solve the problems. This study employed normative legal research with the perspective of legal/ judicial focused on rules/norms of Civil Procedure Law and comparative law through legal principles. It is the study of legal rules which are the benchmarks to behave appropriately. This study was carried out on the norms and principles in the secondary data, which were found in the primary, secondary, and tertiary legal sources.

Keywords

Executorial Strength, Deed of Peace, Civil Dispute

Article Received: 10 August 2020, Revised: 25 October 2020, Accepted: 18 November 2020

\section{Introduction}

In many countries, the non-litigation resolution has developed and gained high confidence to solve carious disputes including business disputes (Sulistiyono, 2002). Meanwhile, in Indonesia, the use of non-litigation resolution whether inside or outside the courtroom has not been developed as in other countries.

In the United States, more than $90 \%$ of civil cases are settled outside the courtroom before those cases reach the full trial. The settlement can be made when the lawsuit is filed or through the direct negotiation between the disputing parties in pre-trial (Mukhtar, 1989: 126). In Singapore, more than $90 \%$ of cases registered for litigation can be settled through Court Annexed ADR (Muladi, 1996: 4). Many Indonesian use judicial institutions to sue the opposing party since the traditional institutions that used to settle the dispute through negotiation disappeared due to modernization (Rahardjo, 1998).

In general, mediation can be defined as the dispute resolution between the disputing parties with the mutual agreement through a mediator who acts neutral and does not make a decision of conclusion but facilitate the dialog between the disputing parties with open, honest, and change of view to reach the consensus (Nugroho, 2009).

The Civil law system in Indonesia uses mediation to resolve civil disputes in the courtroom through peace institution mechanism with its legal product in the form of the deed of peace. The existence of the peace institution is one of the ways to resolve civil disputes through mediation in the civil court. If the peace institution gains confidence from the disputing parties, this kind of dispute resolution will be continued. The peace institution reflects Article 4 paragraph (2) of Law Number 48 of 2009 regarding the Judge Power that "that the judiciary helps seekers of justice and attempt to overcome all the barriers and obstacles in order to achieve the justice that is simple, fast and inexpensive".

Formally, dispute resolution mechanism using a deed of peace is under Article 130 the Herzien Inlandsch Reglement or Civil Procedure (hereinafter referred to as HIR) and Article 18 of the Civil Code. From the two Articles, it can be concluded that the formal requirements for the deed of peace involve: 1) agreement from the two disputing parties; 2) the peace settlement is made based on the existing dispute; 3) the peace settlement must be stated in written form, and the van Dading (deed of peace) Decision shall end the dispute.

Furthermore, in Article 130 paragraph (2) of the Civil Procedure (HIR), it is stipulated that "If on the appointed day the both parties face, the district court through its chairman as the intermediary will try to reconcile them". Thus, it can be seen the importance of the chairman in the peace effort of the disputing parties.

Developing public confidence toward mediation starts with utilizing the peace institution to continuously apply dispute resolution practices. Thus, the use of the peace institution seems urgent at the moment. Besides simple, fast, and inexpensive, the use of peace institution has executorial strength that judge's decision has a permanent legal force as stipulated in Article 1858 of the Civil Code. With this regard, it is expected that the parties do not hold a grudge to each other. If possible, the disputing parties are expected to continue the relationship in the future, especially in terms of 
business relations. In addition, several legal experts and practitioners also confirm the advantage of peace institution.

According to Harahap (1993), no matter how justified the court judgment is, peace settlement would have been more justified. Peace settlement is far more humane without breaking the relationship, in fact, it may strengthen the relationship. On the other side, peace settlement accelerates the dispute settlement and reduces the cost of court to be borne by the parties (Harahap, 1993).

This study examines whether the deed of peace as a legal product of the peace institution has an executorial strength like the judge's decision in cases that have permanent legal force (in kracht van gewisjde).

\section{Research Method}

The method used in this research was normative legal research. This is a research with the perspective of legal/ juridical that focused on rules/norms of the Civil Procedures Law and comparative law through legal principles. It is the study of legal rules that are benchmarked to behave appropriately. In line with the method, the study was carried out on the norms and principles obtained from the secondary data, which were found in the primary, secondary, and tertiary legal materials.

\section{Discussion}

\section{1) Definition and Legal Standing of a Deed of Peace}

There is no standard definition of the deed of peace. According to The Great Indonesia Dictionary, a deed is "a certificate of a statement (information, confession, decision, etc.) regarding a legal affair made according to the applicable law, witnessed and authorized by the officials" (Online, 2017).

The deed of peace can be equalized as the authentic deed. Based on the provision in Article 1868 of the Civil Code that reads: "An authentic deed is one which has been drawn up in a legal format, by or before public officials who are authorized to do so at the location where this takes place". The elements of the deed of peace referring to Article 1868 of the Civil Code are as follows:

a. The deed is made and authorized in accordance with the legal format stipulated by the law.

b. The deed is made before the authorized officials.

c. The deed is made before public officials who are authorized to do so at the designated place.

Referring to the aforementioned description, it can be stated that the deed of peace is an authentic deed with the aims and objectives of the peace settlement. In line with the author's description regarding the peace settlement in the courtroom, the deed for peace referred in this study is the result of the mediation that reconciled the disputing parties in the courtroom in a civil dispute.
The deed of peace is regulated in the Civil Procedure (HIR) and the Civil Code. In Article 130 paragraph (2) of the Civil Procedure (HIR) it is specified that the deed of peace has the same legal force as the court decision. Also, in Article 130 paragraph (3), it is regulated that appeal cannot be requested against such decision for the peace settlement is equated with a court decision that has obtained permanent legal force that attaches the legal force. Thus, referring to Article 195 of the Civil Procedure (HIR) if one of the parties does not carry out the obligation, execution can be requested.

Article 130 of the Civil Procedure (HIR) /154 RBg (Rechtsreglement Buitengewesten) that reads:

1) If on the appointed day the both parties face, the district court through its chairman as the intermediary will try to reconcile them.

2) If such peace can be achieved, then at the time of the trial a deed about it is made, in which both parties are sentenced to keep the promise which is made, which letter will has the power and will be carried out as an ordinary decision.

3) Such decision shall not be allowed to appeal

4) In the period is attempting to reconcile the two parties, it is necessary to use an interpreter so that such article rules are followed for that purpose.

\section{2) The Executorial Strength of the Deed for Peace}

Based on Article 1858 of the Civil Code and Article 130 paragraph (2) of the Civil Procedure (HIR) that reads: "The decision of the peace certificate has the same power as the decision that has permanent legal force".

In Article 1858 of the Civil Code it is stipulated that among the related parties, reconciliation has a power like a Judge's decision at the final stage. The reconciliation cannot be debated by the reason that there is a mistake about the law or by the reason that one of the parties was harmed. In addition, in Article 130 paragraph (2) of the Civil Procedure (HIR) it is stated that "If such reconciliation can be achieved, then at the time of the trial the deed about it is made, in which both parties are obliged to fulfill the agreement that was made, which letter will has the power and will be carried out as an ordinary decision". Referring to the law described previously, the peace settlement made by the Panel of Judge has a permanent legal force (in kracht van gewisjde).

Further, the deed of peace shows that legal remedies in the form of appeal and cassation cannot be sought. This is regulated in Article 130 paragraph (3) of the Civil Procedure (HIR) that the appeal cannot be requested against such decision for the peace settlement is equated with a court decision that has obtained permanent legal force that attaches the legal force. In other words, the peace settlement since the day it is decided by the judge, the contents of the deed of peace are certain with no other interpretation and can be carried out any time at the request of the parties in the deed of peace. However, a legal effort in the form of derden verzet can be taken in the future if another party 
being jeopardized. The reason to do so is the formal defect or material defect in the deed of peace.

In addition, as stated in Article 130 paragraph (2) of the Civil Procedure (HIR) in the last sentence that "which letter will has the power and will be carried out as an ordinary decision" since the deed of peace is equated with the Judge's decision at the final stage. The executorial strength is attached to the deed of peace. Thus, if one of the parties is negligent to implement the deed of peace, execution in the court can be requested. This is in accordance with the command (amar) of the peace settlement that sentences the disputing parties to keep the promises made.

Meanwhile, the procedure for peace settlement execution is the same as the procedure for other judicial decisions that have permanent legal force referring to 195 of the Civil Procedure (HIR).

In addition to having the binding and executorial strength, the deed of peace has the strength of evidence deed like any other authentic deeds. In the peace settlement, there are three strength of evidence deeds, namely:

1) The power of formal proof refers to the certainty of what is written in the deed is actually stated in the deed of peace.

2) The strength of material evidence shows the valid proof of what is stated in the deed

3) The strength of evidence binding refers to the parties to the dispute are bound due to the peace settlement made before the authorized officials.

The essence of dispute resolution through peace is "the willingness" of both disputing parties. The same case can not be tried for the second time by one of the parties since it is nebis in idem.

The third party who is not entitled to the deed of peace is disadvantaged by the peace settlement, the third party can refute (derden verzet). According to Article $378 \mathrm{Rv}$ (Reglement op de Rechsvordering) and Article $379 \mathrm{Rv}$, the third party may propose an objection if:

a. There is a conflict of interest from the third party.

b. The rights of a third party are obviously impaired by a decision.

In addition to the legal effort described earlier, the peace settlement can be reviewed. However, referring to Article 130 paragraph (3), the peace settlement cannot be reviewed unless there is an error stated in Article 1321 of the Civil Code. The settlement may be requested for nullification according to Article 1858-Article 1861 of the Civil Code.

Article 1858 that reads:

"In the last instance, settlements shall have the same validity among one another as a judgment. One cannot appeal such, whether for reasons of errors in the law, or due to another party being jeopardizing."

Article 1859 that reads:
"Notwithstanding this, a settlement may be nullified in the event that there is erroneous information regarding an individual or concerning the subject of the dispute. Settlements may be nullified in all events in which fraud or force have occurred".

Article 1860 that reads:

"One can also request the nullification of a settlement, if due to erroneous facts, it is concluded based on an invalid principle, unless the parties have expressly entered into such agreement regarding such invalidity."

Article 1861 that reads:

"A settlement, concluded pursuant to documents which are subsequently found to be fraudulent, shall be totally invalid."

Therefore in brief, the settlement nullification can only be done if there is erroneous information regarding an individual or concerning the subject of the dispute as well as fraud or force or fraudulent document. This to ensure legal certainty if one of the parties does not carry out the obligation in the deed of peace. Thus, execution can be requested.

The entailment of the previous description is in certain cases. The mediator may ask the mediating parties to submit the material guarantee if one of the parties is found to breach the contract in carrying out the peace settlement. Thus, the peace settlement has a real executorial strength in the peace institution. It has two interpretation that the mediator can ask either one of the parties to submit the material guarantee. Hence, the mediator's discretion includes but is not limited to the parties binding themselves in the peace settlement whether or not the disputing parties to give the material guarantee.

Meanwhile, in other certain cases, the deed of peace may state the deadline to implement the Scheme on the terms of peace. Even though practically there is still an ongoing debate about this, the mediator's discretion to decide this is included but not limited. The mediator also provides a comprehensive understanding of the disputing parties to ensure that the goal of the peace settlement which is final and executorial can be realized.

\section{3) The Solution to the Party Filling Legal Remedies toward the Deed of Peace by Ignoring the Deed of Peace}

In the field of civil procedural law, it is often that the deed of peace made in the district court is neglected by the parties. They include but is not limited to do the legal remedies resulting in unending disputes that had been resolved through the deed of peace.

Based on this foregoing, the alternative solution is indispensable to face the parties file legal remedies toward the deed of peace. This includes the parties who ignore or even consider the deed of peace never existed. Thus the author imposes solutions as follows: 


\section{The Court could not Examine the Case Because of Nebis In Idem Principle}

In the author's opinion, if the district court has decided the deed of peace and a certain party filing a lawsuit against the peace settlement, the district court cannot try the case court a quo for the second time due to the nebis in idem principle. Nebis in idem is a lawsuit that cannot be filed not twice against the same case.

Meanwhile, the law also places the deed of peace as a legal product of the court to have an executorial strength like the judge's decision in cases that have permanent legal force. The provision of Article 1858 paragraph 1 of the Civil Code that successful peace settlement between the disputing parties is equalized with the Judge's decision at the final stage (Harahap, 1993). Article 130 paragraph (2) regulates that the decision of the peace certificate has the same power as the decision that has permanent legal force. The legal force that remains attached after the verdict is announced.

Like any other verdicts that have permanent legal force, a deed of peace has an executorial strength. The executorial strength shows that if the defeated party does not carry out the judge's decision voluntarily, the disadvantaged party can request the execution of the decision to the district court. This is in line with the provision of Article 196 of the Civil Procedure (HIR) that reads: "If the defeated party does not unwilling or negligent decisions insufficient contents it well, then the parties won insert request either verbally, that is to Chairman of the State Court in Article 195 paragraph (1), the Chairman summoned the parties defeated it and advised that it suffice that decision in time a maximum of 8 days."

The equalization of a peace settlement with the verdict that has permanent legal force, further remedy in term of appeal cannot be proposed. This is in accordance with Article 130 paragraph (3) of the Civil Procedure (HIR) that reads: "Such decision cannot be appealed." Thus, the peace settlement cannot be appealed. In addition, this provision is also written in the decision of Supreme Court No. 975 K/Sip/1973 which said, based on Article $154 \mathrm{RBg} / 130$ of the Civil Procedure (HIR), the peace decision is the highest decision, there is no appeal and cassation against it.

The deed of peace that has been strengthened by the court decision cannot be used as the basis to file the breach of contract since the deed of peace is the result of the mediation of the civil case and has been decided in the court with the deed of peace having permanent legal force. Like the judge's decision, the deed of peace has an executorial strength.

Further, not carrying out the deed $\mathrm{f}$ peace falls under the category of breach of contract since the party does not adhere to what has been agreed upon. However, the resolution is different from the ordinary agreement since the deed of peace has a permanent legal force. Thus, the deed of peace cannot be used as the basis for the breach of contract litigation. Just like any other judge's decision that has permanent legal force, if the parties are negligent to the deed of peace, execution can be requested.

It is a logical legal consequence when the court has decided the reconciliation. However, one of the party does not carry out the obligation, the new lawsuit, appeal, and cassation cannot be proposed but execution. Thus, the new lawsuit is unacceptable because of nebis in idem. This refers to the decision of Supreme Court No. $647 \mathrm{~K} / \mathrm{sip} / 1973$ that The absence or existence of ne bis in idem principle is not solely determined by the parties to dispute, but the disputing object has been given a certain status by an earlier decision of the District Court and has definite legal power and the reason is the same.

In the case that there is a court decision in the form of deed of peace, but there is a party that tries the lawsuit for the second time, the court should not examine the case since it is nebis in idem. Technically, this kind of decision can be made in the form of interlocutory decision after the exception. Alternatively, this kind of decision can be taken in the form of final decision of the case being disputed. However, the author tends to follow the view that the decision that nebis in idem is made interlocutory decision before following it up the next process in the main trial of the case.

The next question is: how if one of the disputing parties does not propose an exception which is the basis for the interlocutory decision toward the lawsuit after the making of the peace settlement?

It is known that the interlocutory decision is preceded by the exception proposed by the defendant. However, according to the author's opinion, there is no explicit provision that imposes the interlocutory decision by the Panel of Judges that must be preceded by an exception from the defendant. This is in line with Harahap that "... it is not merely the public order, but also the intention that gives ex officio power to the judge to examine and decide the interlocutory although it is not proposed as an exception" (Harahap, 2015)

Based on the author's exploration, the procedure for proposing exceptions is regulated in some Articles, they are Article 125 paragraph (2), Article 133, Article 134, and Article 136 of the Civil Procedure (HIR). Meanwhile, there are differences in how the procedure of proposing and the time the exception is submitted in the examination according to the type of exception concerned.

According to the provision of the Civil Procedure, the procedure of submitting exception is divided into two. They are related to the absolute and relative authority (Exceptio Declinatoir). The proposal of the exception of absolute competence is regulated in Article 134 of the Civil Procedure (HIR) and Article 132 of Rv. It can be concluded that the exception of absolute competence can be proposed by the defendant at any time during the process of examination is held at the first degree of the trial until before the decision is made (District Court). In other words, the 
defendant can propose the exception of absolute competence from the beginning until before the verdict is made. It can even be filed at the level of appeal and cassation. Further, Article $132 \mathrm{Rv}$ has regulated if the judge is not authorized due to the type of the case, even though he is objected due to his no authorization, he is obliged to declare himself not authorized. This means that a judge having ex officio power must declare himself not authorized to try the case he is examining if the case is filed absolutely outside of his jurisdiction or falls within another jurisdiction. This obligation must be carried out ex-officio despite the defendant does not propose an exception regarding that.

\section{Criminal Legal Effort Can be Made}

As the foregoing description, the law places the deed of peace as a legal product of the court to have an executorial strength like a judge's decision in cases that have permanent legal force. Article 1858 paragraph (1) of the Civil Code that successful peace settlement between the disputing parties is equalized with the Judge's decision at the final stage (Harahap, 2015). Article 130 paragraph (2) of the Civil Procedure (HIR) regulates that the decision of the peace certificate has the same power as the decision that has permanent legal force. The legal force that remains attached after the verdict is announced.

At the application level regarding the ownership of material assets that ends up in the peace institution, it often causes the next problem. Nevertheless, a question arises: how is the settlement of ownership of material assets that have been decided through the peace institution with one of the disputing parties still "forces" to possess the object illegally? In order to answer the question, the civil settlement is not enough to resolve the dispute. It enters another facet of a legal system which is criminal law.

For instance, in the land dispute between A and B. In the peace settlement between A and B made by Bekasi district court, it was agreed that A as the owner of the land by paying a sum of money to B. However, B claimed that the land is his and cultivated the land without the permission of A. Thus, according to the author, this is included in the scope of criminal law. The logical consequence of this is a criminal lawsuit since there is no "pre-judicial" dispute to this.

Further, the pre-judicial substance is related to the provision of the Supreme Court Number 1 Year 1956 ("Perma 1/1956") in Article 1 Perma 1/1956 that reads:

"If a criminal case examination is to be decided in the case of a civil case on an item or about a legal relationship between two specific parties, then the criminal case examination may be suspended to await a court ruling in the examination of a civil case about the civil rights or the absence of that civil right."

It is described that a criminal case to be decided in the case of a civil case on an item or about a legal relationship between two specific parties, the examination of the criminal case may be suspended waiting for the court ruling in the examination.

That the postponement of the criminal case mentioned before can also be based on the Jurisprudence of the Supreme Court (MA), decision Number 628 K/Pid/1984. In this decision, the Supreme Court ordered the Bandung High Court to wait for a court ruling with permanent legal force, which decided on the status of land ownership.

Basically, in the law enforcement process, the regulation on this matter has been regulated in Article 81 of the Criminal Code that reads: "The suspension of a penal prosecution in case of a prejudicial dispute shall suspend the lapse of time."

Being connected to Article 81 of the Criminal Code which is an advanced article of Article 78, Article 79, Article 80 of the Criminal Code that dispute shall suspend (geschorst) the lapse of time in case of a prejudicial dispute. A prejudicial dispute that must be resolved through civil law before being preceded to criminal law. The provision is regulated in the form of 'suspension (schorsing)' refers to the time elapsed before it is suspended will be taken into account. As long as the civil procedure is ongoing, the lapse of time shall be suspended. This is intended to ensure that the defendant is not given the opportunity to settle the civil case to fulfill the lapse of time of the criminal.

\section{Conclusion}

1. The legal basis for resolving civil disputes through the deed of peace in Indonesia is regulated in Article 130 paragraph (2) of Civil Procedure (HIR), Article 1851 of the Civil Code, and PERMA Number 1 Year 2016. However, not many people have used this to resolve their disputes.

2. Among the advantage of civil dispute resolution through peace institutions that the decision of the deed of peace has a permanent legal force so it has the executorial strength. This implied that if one party entitled in the deed of peace try the case for the second time, the district court should not examine the case because it is nebis in idem. Also, the settlement of ownership of material assets that have been decided through the peace institution with one of the disputing parties still "forces" to possess the object illegally, the civil settlement is not enough to resolve the dispute. It enters another facet of a legal system which is criminal law.

\section{References}

[1] Sulistiyono, Adi. (2002). "Mengembangkan Paradigma Penyelesaian Sengketa Non-Litigasi Dalam Rangka Pendayagunaan Alternatif Penyelesaian Sengketa Bisnis/Hak Kekayaan Intelektual". Disertasi Program Doktor Program Pascasarjana, Fakultas Hukum Universitas Diponegoro, Semarang, 2002. 
[2] Harahap, M. Yahya. (1993). Ruang Lingkup Permasalahan Eksekusi Bidang Perdata, Jakarta: Gramedia Pustaka Utama.

[3] Harahap, M. Yahya. (2015). Pembahasan Permasalahan dan Penerapan KUHAP, cet. XV, Jakarta: Sinar Grafika.

[4] Mukhtar, Sofyan. (1989). Mekanisme Alternatif bagi Penyelesaian-Penyelesaian Perdata dan Dagang”. Varia Peradilan, 41.

[5] Muladi. (1996). Korporasi Transnasional dan Pengaruhnya Terhadap Tindak Pidana Ekonomi Dalam Era Globalisasi. Makalah disampaikan di Jakarta: Universitas Trisakti, 20 Juni.

[6] Nugroho, Susanti. (2005). Mediasi Sebagai Alternatif Penyelesaian Sengketa, Jakarta: Telaga Ilmu Indonesia.

[7] Rahardjo, Satjipto. (1998). Pelaku Gugat Menggugat. Kompas, 25 Februari.

[8] (On-Line), tersedia di:https://kbbi.web.id/akta (2 Agustus 2017). 